\title{
A Short History of Long-Term Care in Nova Scotia*
}

\author{
Jasmine Mah, MD, MSC ${ }^{1,2}$, Benjamin Gallup, BA, BEd ${ }^{3}$ \\ ${ }^{1}$ Department of Medicine, Dalhousie University, Halifax, NS, Canada, ${ }^{2}$ Department of Health Policy, \\ London School of Economics \& Political Science, London, UK; ${ }^{3}$ Ontario College of Teachers, Toronto, ON, Canada
}

https://doi.org/10.5770/cgj.24.464

\begin{abstract}
The needs of older adults living in long-term care in Nova Scotia and across Canada are frequently ignored. There is historical precedent for this, as the voices of the poor and vulnerable have been under-represented throughout history. This paper aims to summarize the history of long-term care in Nova Scotia, Canada from its 17th-century origins to the end of the 20th century. The influences of key events, policies and concepts are examined chronologically: the systems implemented in Nova Scotia by French and later British colonists, the movement to delineate between categories of poor, the rise and fall of workhouses, and the development of social welfare legislation in Canada in the 20th century. Additionally, the surprisingly persistent stigmatization of poverty and dependence, and social versus health framing for older adult care, are all discussed. The authors hope that, by reflecting on the evolution of long-term care, this may result in better understanding of why contemporary problems are entrenched in our institutions. Through this understanding, tangible solutions might become more feasible.
\end{abstract}

Key words: institutional care/residential care, nursing homes, history, marginalized populations

\section{INTRODUCTION}

"The core of the problem is that the present [long-term care] system was never planned; it simply evolved."(1) Contemporary concerns over quality of care and limited resources are not novel; the same discourses have been prevalent throughout the history of long-term care (LTC). Fred MacKinnon, director of Nova Scotia's Senior Citizens' Secretariat, commented: “We can never truly discern where we are going if we have no clear understanding of how we came to be. ${ }^{(2)}$ This paper aims to summarize the history of LTC in Nova Scotia (NS) from its 17 th-century origins to the end of the 20th century. The authors hope that, by reflecting on the evolution of long-term care, this may result in better understanding of why contemporary problems are entrenched in our institutions.

\section{Setting the Stage}

An overview of the history of LTC is visualized in Figure 1. Several a priori concepts are useful to help understand the complex history of LTC. As the paper progresses, bolded texts will raise questions linking historical context to current LTC systemic issues.

\section{Concept 1: A Eurocentric Historical Perspective}

Regarding histories of the African NS population and Mi'kmaq older adults, "it has been proven a difficult task to find the voices and experiences of poor people; it has been even more difficult to find and record the voices of the African-Nova Scotians and even more so of the Mi'kmaq". (3) Most remaining primary sources are government documents, reflecting the attitudes of those in positions of power, which include a preponderance of white male perspectives. ${ }^{(4)}$

\section{Concept 2: The Notion of Older Adults as a Distinct Population was Minimal Prior to 20th-Century Canada}

"Life expectancies were lower, the age of retirement higher, and institutionalized care, for the specific ailments of aging, was almost non-existent". ${ }^{(5)}$ Only in 1875 did commissioners provide a breakdown by age in the Halifax Poor Asylum. ${ }^{(6)}$ These institutions did not recognize the unique needs of older adults; nonetheless, they evolved into today's LTC facilities.

\section{Concept 3: Social Services \& Charity, Not Healthcare, Historically Predominated Older Adult Care}

In NS, LTC transferred to the Department of Health from the Department of Community Services in 2000. ${ }^{(2)}$ LTC maintains the governance model, culture, and perceptions attached to social welfare. Social welfare frequently provided subsistence and harsh stigmatization rather than hope and recovery. ${ }^{(7,8)}$

\footnotetext{
*This manuscript is a highly revised and condensed edition of an essay that won the 2020 Royal College of Physicians and Surgeons of Canada's Charles Peter W. Warren History of Medicine Essay Prize.
} 


\section{Colonization: 17th and 18th Centuries}

The first permanent European settlement in NS, Port Royal, was built in 1605 . With strong ties to France and Catholicism, care of the poor and elderly was Church responsibility. ${ }^{(5)}$ French NS paralleled the Church's poor-relief role of nearby Quebec. One critique of their approach is they accepted "things as they are;" this often "stood in the way of the rehabilitation and the education of the disabled and handicapped."(5)

Acadian society also featured communal care: [B]lood ties created by kinship formed a basis for the establishment of a system of mutual aid, solidarity, and independence, in which the wealthier distributed their surplus to those whom war or natural disaster had touched. ${ }^{(9)}$

In the mid-late 18 th century, Britain became Canada's administrator. Contrasting with the "Acadian extended family", the new settlers

"[W]ere governed by a titled elite who considered themselves to have a divine right to rule... Because of this elitism, average citizens...were routinely denied basic human rights and freedoms."(10)

This attitude can be observed in Cornwallis' claim that most European settlers were "poor, idle, worthless, vagabonds". ${ }^{(8)}$ From the beginning, Halifax was known by officials as an entrance for undesirables, particularly impoverished populations.
Families were primarily responsible for infirm older adults. The oldest sons took care of parents to maintain title to property upon death. Deserting your family meant deserting your inheritance. ${ }^{(7)}$ Poor people without family were auctioned off or boarded out to the community:

Once a year the poor were auctioned off to the lowest bidder in order that the taxpayers would have as little to pay as possible... As a boy those auctions were downright revolting to me, and to many others of that time... ${ }^{(11)}$

Owners were paid by Overseers of the Poor for housing and support, resulting in abuse, fraud, and corruption. ${ }^{(3)}$ This practice was slowly replaced by workhouse usage.

The first workhouse established in NS was in Halifax in 1758. Tellingly, it included "a whipping post."(12) These institutions were punitive; care and rehabilitation were afterthoughts. Older inmates suffered the most; at the Sidney Mines Poor House, the provincial inspector reported inmates who were "all old and feeble... The house is open to the wind...They complain that the overseers never come to see how they fare...."(13)

The British North American model for poor relief can be traced back to the dissolution of Catholic monasteries in England, culminating in the Elizabethan Poor Laws from 1547 to 1601 . The 1601 Poor Relief Act is credited with a

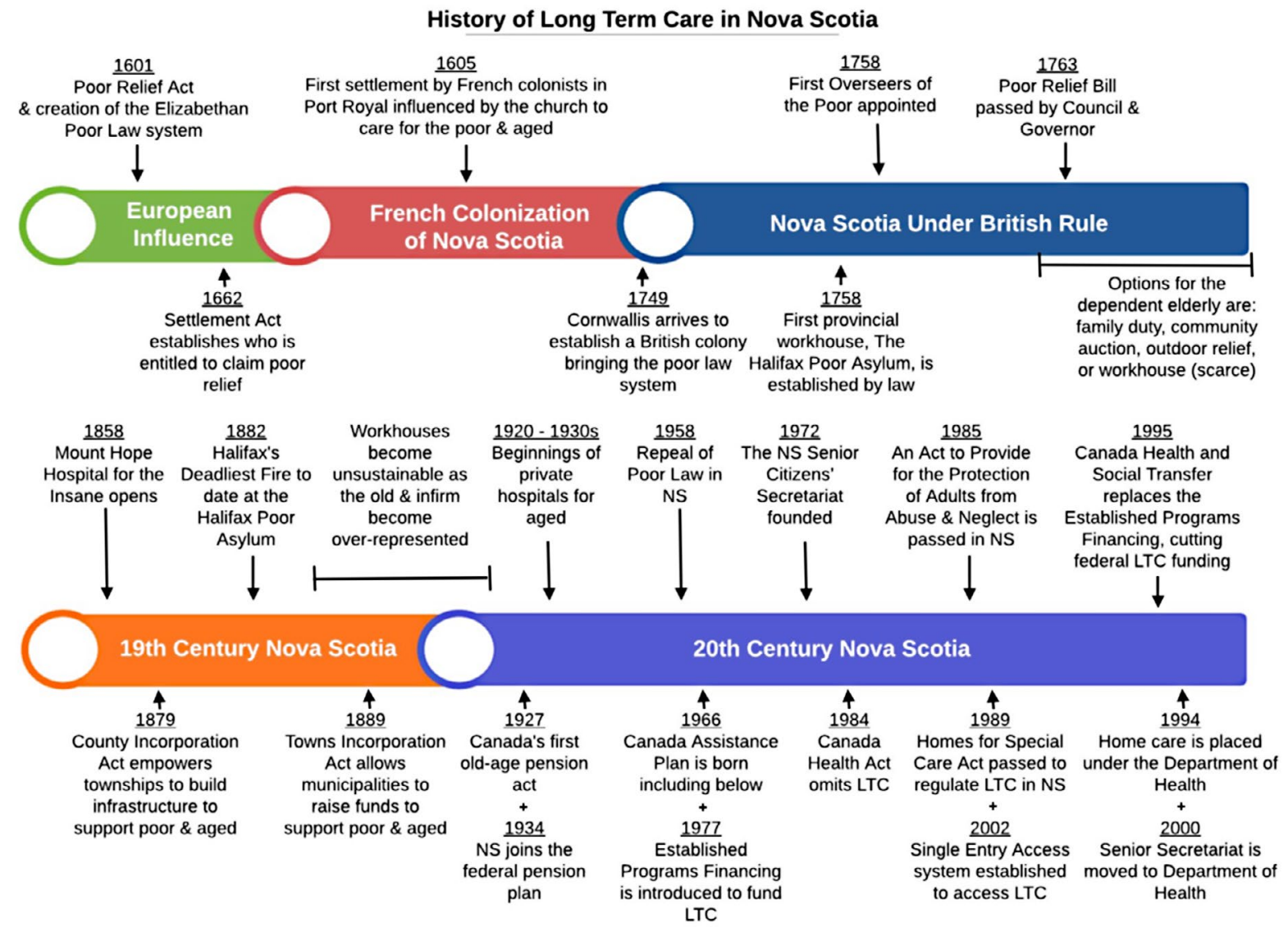

FIGURE 1. Key Dates in the History of Long-Term Care in Nova Scotia, Canada 
legacy of viewing "poverty as a reflection on the worth and character of the person". ${ }^{(5)}$ Specifically, this law defined the deserving poor: individuals deemed not responsible for their poverty and worthy recipients of charity. ${ }^{(7)}$ But this led to accusations that the undeserving poor were responsible for their poverty for repudiating "the Protestant Work Ethic", paving the way for neglect and abuse of the poor and aged. ${ }^{(3,8)}$ Thus the orphaned, incapacitated, insane, and old were pushed into workhouses, which adhered to two fundamental principles. ${ }^{(7)}$ First, acceptance of charity by workhouse residents (called "inmates") was equated with loss of freedom and recognition to submit to any work dictated by the workhouse. Second, because the poor were inherently sinful, only absolute essentials were necessary. "The buildings were designed to be intimidating, imposing, and institutional...it was assumed that no able-bodied person would accept this form of assistance because of the horrible conditions in the workhouse."(3)

Does the cultural view of poverty and dependence as a moral failing continue to influence how we institutionalize older adults?

Another legacy of the Poor Law is local municipalities shouldering responsibility for poor older adults. Following England, NS in the 1700s was divided into poor districts and townships. An Overseer of the Poor was appointed by each municipal council to manage funds. Settlement laws described who had a right to receive support from a poor district based on place of birth, length of residence, ownership of property, and tax payments. ${ }^{(8)}$ Transients, not meeting settlement criteria, were lashed and banished. Repeal of the Poor Relief Act in NS did not occur until 1958, and funding according to settlement laws was not formally abolished until $2000 .^{\left({ }^{8}\right)}$

\section{9th Century}

This period brought distinction between categories of poor; certain populations were not beyond hope and could be rehabilitated. Specialized homes for specific groups were built: orphanages for children, hospitals for the mentally ill or disabled, and homes for the blind or deaf. Once those who could be reformed had left, the old or chronically ill remained behind in the workhouses. Older inmates were marginalized: they were "not only physically incapable of working but could never be cured or expected to return to the working community."(6) "Eventually, many of the poor houses in Nova Scotia were transitioned into seniors' homes"; (3) therefore, "homes for the aged developed by default rather than by design."(6)

Hospitals also excluded non-acute older adults. At Mount Hope Hospital for the Insane (built 1858), superintendent James De Wolf noted increased older adult admissions, with the hospital forced "to serve as a resting place for those advanced in years." He complained, "that if unchecked, the growing number of useless classes such as the aged, would reduce the hospital 'to the lowest degree'."(14) At the Victoria General Hospital, similar rhetoric occurred even though the hospital was built for the poor. ${ }^{(14)}$ The sentiment that chronic cases be moved out of provincial hospitals and back into municipal jurisdiction resulted in older adults being returned to the peripheral workhouses or to the Halifax Poor Asylum. Today, similar offloading takes place when patients do not require tertiary care but cannot go home; how much progress has been made?

While the townships were responsible for their poor based on settlement laws, townships lacking funds sent them to Halifax, creating over-crowdedness and straining the provincial budget. ${ }^{(6)}$ Increasingly indebted, the commissioner for the poor in Halifax wrote to townships requesting payment for the new arrivals. The townships did not respond. ${ }^{(6)}$ Consequently, the Halifax-based provincial government passed a series of legislation (most notably, the Towns Incorporation Act of 1889) allowing municipalities to raise and keep profits made by their poor, and championing institutionalization as the most economical response to poverty. ${ }^{(6-8)}$ As a result, the late 1800s saw a big increase in the number of NS workhouses; from only nine workhouses prior to 1879 to one built in almost every NS county, as they now had the power to finance their workhouses and reap any profits. ${ }^{(8)}$

Unfortunately, there was an increasingly "marked difference between county institutions for ... able bodied workers, and those for predominantly aged inmate populations, the non able bodied workers." ${ }^{\prime(6)}$ As new institutions developed for specific poor populations, and the aged and chronically ill were offloaded from hospitals, the workhouses became unsustainable, with fewer resources and worsening conditions. Notable examples of neglect are the 1882 Halifax Poor Asylum fire and the 1886 Poor of Digby scandal. Halifax's deadliest fire in its history claimed the lives of 31 inmates, most of whom were older or infirm. From the Chronicle Herald on November 6, 1882, "[c] ]onditions within the Poor House were harsh, aimed at providing relief to the inmates at the lowest possible cost..." ${ }^{(8)}$ In the Digby scandal, a government investigator unearthed the deplorable state of old paupers. ${ }^{(15)}$

\section{0th Century}

Initially, there was minimal change to the conditions of poor older persons who were becoming the majority living in workhouses. The Superintendent of the West Hands workhouse wrote of this:

"When I look back on this experience, it was a nightmare. The inmates were housed in a little bedroom...The windows were nailed shut. The doors were locked at night and the toilet facilities consisted of a chamber pot under each bed." ${ }^{(8)}$

Private hospitals appeared in the 1920s/1930s out of desperation to avoid workhouses; however, besides providing shelter, they "offered practically no nursing service...and were not deserving, in fact, of the name hospital." (16) Like workhouses, these institutions would also become precursors to modern LTC facilities.

Groundbreaking legislative changes included societal attempts to encourage financial preparation for old age. ${ }^{(17)}$ In 1927, the federal Old Age Pension Act was passed. ${ }^{(17)}$ Unemployment insurance and family allowances were introduced 
in the 1940s. ${ }^{(17)}$ Unfortunately, the institutionalized were excluded from these programs. In 1952, federally administered pensions were lowered to 65 years old, expanding the number of its beneficiaries. Institutionalized older adults finally gained suffrage in 1954. ${ }^{(8)}$

Many politicians felt that a federal pension program would reduce the number of older persons in institutions, even saying that LTC would become obsolete. ${ }^{(5)}$ Social security was heralded as the solution to undignified institutionalization. Interestingly, while this helped some to live independently, the total number of institutionalized older adults increased after its introduction. In Ontario, with increased social security funding, public funding for institutions decreased, resulting in privatization. ${ }^{(1)}$ Placement into LTC came not only from poverty, but other factors like family choice and physical/ cognitive dependencies. When Canada deinstitutionalized mental hospitals, many older adults had no choice but to seek shelter in LTC facilities. ${ }^{(18)}$ The director of NS's Senior Citizens' Secretariat argued that, for these services to be affordable, a large community volunteer component is required. Since personal care is an integral part of LTC, are healthcare professionals the ideal stewards for this population?

Also on the federal agenda was the nationalization of healthcare. From 1945 to 1970, despite parliamentary debates to put LTC on the agenda, the focus remained on physician and hospital-based medicine. A 1966 Senate report indicated little aid was offered to LTC. "So desperate is the situation that even nursing homes of such poor quality that according to the authorities they 'should not be in operation' have long waiting lists". ${ }^{(19)}$ The same report noted that health policy "was preoccupied with maternal and child health to the exclusion of other age groups." (19) Overall, a "hands off approach characterized [the federal government's] relationship to seniors' care." ${ }^{(18)}$ In 1984, the Canada Health Act said little with regard to LTC. The Canada Health Act is regarded as the guiding national principles for the healthcare system, yet delivery of services remains a provincial/territorial responsibility. While the Act does mention adult residential care services and nursing home services as part of "extended health services", there are no further regulations or funding conditions to standardize LTC across provinces/territories. ${ }^{(20)}$ This omission ensured that LTC was placed outside the scope of the Act's universal, portable, comprehensive, accessible, and public administration tenants. ${ }^{(21)}$ One wonders: What might LTC look like today if it had to comply with the tenants of the Canada Health Act?

\section{CONCLUSION}

By revisiting the history of LTC in Nova Scotia, it becomes easier to understand the current system of caring for older adults in this province. LTC in NS has evolved from a colonial view of poverty and dependence as a moral failing, influencing the institutionalization patterns, attitudes, and value placed towards LTC, which are exemplified in its exemption from the Canada Health Act. And while NS was presented as a case report, this discussion has national relevance since, "one of the greatest gaps in the healthcare system in Canada [remains]...the perpetual insufficiency of beds, services, and other facilities, specifically designed for convalescent and chronically ill patients". (16)

To end on a more optimistic note, one final question is posed: As an ever evolving process, perhaps the current LTC system is not broken; rather, is it possible that a LTC system that works has not yet been created?

\section{ACKNOWLEDGEMENTS}

We would like to sincerely thank Dr. Melissa Andrew, for her support and encouragement. Additional thanks to the lead author's thesis advisory committee: Dr. Ken Rockwood, Dr. Janice Keefe, and Professor Susan Stevens. The lead author would also like to give her gratitude for the scholarships provided by the following organizations: Department of Medicine at Dalhousie University, Dalhousie University's Clinician Investigator Program, Research Nova Scotia, and the London Goodenough Association of Canada.

\section{CONFLICT OF INTEREST DISCLOSURES}

The authors declare that no conflicts of interest exist.

\section{REFERENCES}

1. Daly T. Dancing the two-step in Ontario's long-term care sector: More deterrence-oriented regulation $=$ ownership and management consolidation. Stud Polit Econ. 2015;95(1):29-58.

2. MacKinnon FR. Nova Scotia's aging population. In: MacKinnon FR. Reflections: 55 years in public service in Nova Scotia. Halifax, NS: Fernwood Publishing \& Maritime School of Social Work; 2004.

3. Thompson B. A wholesome horror: poor houses in Nova Scotia. Halifax, NS: SSP Publications; 2017.

4. Simpson C. The treatment of Halifax's poor house dead during the nineteenth and twentieth centuries (MA thesis). Saint Mary's University, Halifax, Nova Scotia; 2001.

5. Emodi B. A history of long-term care facilities for the elderly in Canada. Ottawa: Canada Mortgage and Housing Corporation; 1977. Report No.: NH18-25/4-1977E-PDF. Available from: http://publications.gc.ca/site/fra/9.823686/publication.html

6. Desroches C. For them but never really theirs: finding a place for the "Aged" within state funded institutions in nineteenthcentury Nova Scotia. J Can Historical Assoc. 2009;20(1):57-83.

7. Haber C. History of long-term care. In: Rowles GD, Teaster PB, eds. Long-term care in an aging society: theory and practice. Halifax, NS: Springer Publishing Company; 2015. p.37-49.

8. Senior Scribes of Nova Scotia. Lucy S, ed. Poverty, poor houses and private philanthropy. Halifax, NS: Communications Nova Scotia; 1996.

9. Daigle J, Theriault L, Arsenault S, et al. The Acadians of the Maritimes: thematic studies. Moncton, NB: Centre d'Etudes Acadiennes; 1982.

10. Paul D. We were not the savages: First Nations history collision between European and Native American civilizations, $3^{\text {rd }}$ ed. Halifax, NS: Fernwood Publishing Co.; 2006. 


\section{MAH: HISTORY OF LTC IN NOVA SCOTIA}

11. Foster M. Annapolis Valley Saga. Windsor, NS: Lanceplot Press; 1992

12. Akins T. History of Halifax city. Halifax, NS: Nova Scotia Historical Society; 1895.

13. Journal and Proceedings of the House of Assembly of the Province of Nova Scotia. Public charities report of the Inspector of County Asylums, Poor farms, etc, by AC Page, Inspector of County Asylums. Halifax, NS: Queens Printer, Appendix 3B, p.18; 1899. Available from: http://0-nsleg-edeposit.gov.ns.ca. legcat.gov.ns.ca/deposit/b10564470.htm

14. Journal and Proceedings of the House of Assembly of the Province of Nova Scotia (JHANS). Nova Scotia Hospital for the Insane by J DeWolf, Medical Superintendent, Halifax, NS: Queens Printer, Appendix 6\&10; 1863. Available from: http://0-nsleg-edeposit .gov.ns.ca.legcat.gov.ns.ca/deposit/b10564470.htm

15. Journal and Proceedings of the House of Assembly of the Province of Nova Scotia (JHANS). Public charities report: the poor of Digby, Commissioner's Report in the matter of certain charges affecting the treatment of the poor in the County of Digby. Halifax, NS: Queens Printer, Appendix 10, p.18-19; 1886. Available from: http://0-nsleg-edeposit.gov.ns.ca.legcat .gov.ns.ca/deposit/b10564470.htm

16. Agnew, H. Canadian hospitals, 1920 to 1970: a dramatic half century. Toronto, ON: University of Toronto Press; 1974.

17. Canadian Museum of History. The history of Canada's public pensions [Internet]. Ottawa: Human Resources Development Canada; 2019. Cited September 6, 2019. Available from: https:// www.historymuseum.ca/cmc/exhibitions/hist/pensions/cpp -m1915_e.html\#govern

18. Twomey A. The marginalization of long-term care in Canadian federal policy making [Internet]. Queen's Policy Rev. 2013;3(3):1-19. Available from: https://www.queensu.ca/sps/ qpr/sites/webpublish.queensu.ca.qprwww/files/files/10\%20 marginalization $\% 20$ long\%20term\%20care.pdf

19. Senate of Canada. Final Report of the Special Senate Committee on Aging in Canada. Ottawa: Queen's Printer; 1966.

20. Canada Health Act, R.S.C, c. C-6. Ottawa: Government of Canada; 1985. Cited September 7, 2019. Available from: https:// laws-lois.justice.gc.ca/eng/acts/C-6/page-1.html

21. Maclean MJ, Greenwood Klein J. Accessibility to long-term care: the myth versus the reality. IN: Stephenson M, Sawyer E, eds. Continuing the care: the issues and challenges for long-term care. Ottawa, ON: CHA Press; 2002.

Correspondence to: Jasmine Mah, MD, MSC, Department of Medicine, Dalhousie University, QEII Health Sciences Centre, VG Site, Suite 442 Bethune Building, 1276 South Park St., Halifax, NS Canada B3H 2 Y9

E-mail: jmah@dal.ca 